\title{
Tayler Rule for a Highly Dollarized Country the Case for Albania
}

\author{
Altin Zefi \\ $\mathrm{PhD}$, European University of Tirana, Faculty of Economics and Information technology, Department of Finance
}

\begin{abstract}
Targeting nominal interest rate as a policy rule to achieve the primary purpose of stable prices has become a standard monetary policy for Central Banks. Albania switched in 2008 from targeting money supply, M3, to targeting nominal interest rate. Taylor Rule, as defined by John Taylor in his 1992 paper, has become widely used as a means to establish the policy interest rate for Central Banks. This paper implies a conceptual framework where policy rules are a means to a more effective monetary policy. The Taylor Rule has influenced the decision of policymakers on interest rate. Taylor presented his findings at the Carnegie-Rochester Conference on Public Policy in November 1992 and can be stated as a mathematical identity: $r=p+.5 y+.5(p$ - 2) +2. But can we use this rule universally? What about countries that are dollarized where the interest rate of loans paid in foreign currency depends on the interest rate of other countries? We expect to find that the standard Taylor Rule is not adequate and the domestic country, that is highly dollarized, should adopt an improved version that incorporates the expected interest rate, expected inflation and growth of the foreign country (ies) whose currency is present at large in the domestic economy. We propose a coefficient that puts downward pressure on the domestic nominal interest rate target when the foreign country's (the country that has "dollarized" the domestic economy) lowers its nominal interest rate target. And when the nominal interest rate differential between $t_{n}$ and $t_{n-1}>0$ than this coefficient will have a upwards pressure. Thus we propose an adjusted Taylor Rule for foreign country interest rate and exchange rate to take the following form:
\end{abstract}

$i_{t}^{h_{t}}=\gamma_{q} i_{t}^{*}+\gamma_{\pi} E_{t} \pi^{h_{t+1}}+\gamma_{y} y_{t}^{h_{t}}+\gamma_{s t} q_{t}+u^{h_{m t}}$

Keywords: Tayler rule, dollarized, country, Albania

\section{Introduction}

Inflation targeting is a new policy followed mostly in the last thee decades. Inflation targeting started with New Zeland, in 1990 , and then spread to almost all countries. With the dawn of inflation targeting era by world central banks inflation has been maintained better under control. More freedom, through laws, given to central banks has helped to allow central banks to formulate and carry out policies to achieve its goals.

The economy can be influenced, cooled down or accelerated, by two instruments: First is the fiscal policy. This policy tool is in the control of the government. Through taxation and government spending the government can affect the national demand and GDP. The downside to using fiscal policy won't be treated here but suffice to say that the policy is widely debated.

The second tool to use is the monetary policy. This tool is in the control of the central bank. The central bank presses dhe pedal, i.e. pumps money into the economy through lower interest rates, repo purchases or other unconventional ways, when it feels that the economy is slowing down or sluggish. But it also can cool of the economy if growth is above potential or inflation is higher than the target. 


\section{Literature Research}

\section{Operational Instruments of Monetary Policy}

\section{Problems with using Money supply instrument}

Dollarized countries tend to have lower inflation in part due to a tight money supply caused by the dollarization (see Zefi, Shehu, 2015).

In dollarized economics the transition mechanism of MP is hampered by the foreign currency widely used in the economy. In Albania dollarization of deposits is at $60 \%$. Euro is used widely by the population for pricing and exchange. The Central Bank of Albania, or any country with similar situation, can influence only $40 \%$ of money supply. Any increase of money supply by the QTM targets with the formula:

\section{Quantitative Theory of Money for a dual currency country like Albania}

QTM states that: "... if a change in the quantity of (nominal) money were exogenously engineered by the monetary authority, then the long-run effect would be a change in the price level (and other nominal variables) of the same proportion as the money stock, with no change resulting in the value of any real variable." (McCallum, Nelson. 2010)

The QTM is expressed as a mathematical identity in the form of:

$$
M^{*} V=P^{*} Q \text {. }
$$

In other words: GDP of Albania $=M^{*} \mathrm{~V}$.

So according to this identity, by taking $V$ as stable BoA needs to print money at the speed the GDP grows plus the targeted inflation.

If GDP grows at $3 \%$ a year and the targeted inflation is 3 percent a year than BoA needs to print $6 \%$ more money, increasing the monetary base by $6 \%$.

These data suggest that in excess of $50 \%$ of the money supply used to fuel the economy is already in FC.

The adjusted Phisher's identity for such country would be:

$$
(\mathrm{DMB}+\mathrm{FMB})^{*} \mathrm{~V}=\mathrm{GDP} \text { of Albania }
$$

Where: $\mathrm{DMB}=$ Domestic Monetary Base, FMB = Foreign Monetary Base, $\mathrm{V}=$ velocity, times money changes hands in a year.

The relationship between DMB and FMB is such that foreign currency monetary base is a percentage of the domestic monetary base.

$$
\mathrm{FMB}=\mathrm{x}^{*} \mathrm{DMB}
$$

Where $\mathrm{x}=\mathrm{a}$ quotient that express the relationship between FMB and DMB.

In this case we can change in Phisher's identity as:

$$
\left(D M B+x^{*} D M B\right)^{*} V=\text { GDP of Albania }
$$

This identity can be simplified to take the form as below:

$$
\operatorname{DMB}^{*}(1+x)^{*} V=\text { GDP of Albania. }
$$

This conclusion is very important for monetary policy. It states that if the GDP grows at $3 \%$ and BoA's goal is to have $3 \%$ inflation than:

$$
\text { Monetary Base increase }=6 \%(1+x) \text {. }
$$

This formula (5) implies that if money supply in Albanian Lek is equal to Foreign Currency, or $x=1$, GDP growth is predicted to be $3 \%$ and targeted inflation is 3\% then than BoA needs to increase monetary base by: 


\section{Monetary Base increase $=6 \%(1+1)=12 \%$.}

This is a very important conclusion and we are going to test it using the long term relationship between M2 and Inflation as well as a bivariate function of the influence of credit and deposit euroization on inflation and GDP growth.

Central Banks use mainly interest rate as an intermediate tool for achieving the targeted inflation. In the past money supply has been used but nowadays policymakers monitor money supply but don't hardly use it.

\section{Problems with using interest rate as instrument of monetary policy}

Real reason behind interest rate fluctuations: Interest rate is the equilibrium rate of demand for money and supply of money. A rise in the interest rate could be due to one of them.

\section{Real interest rate}

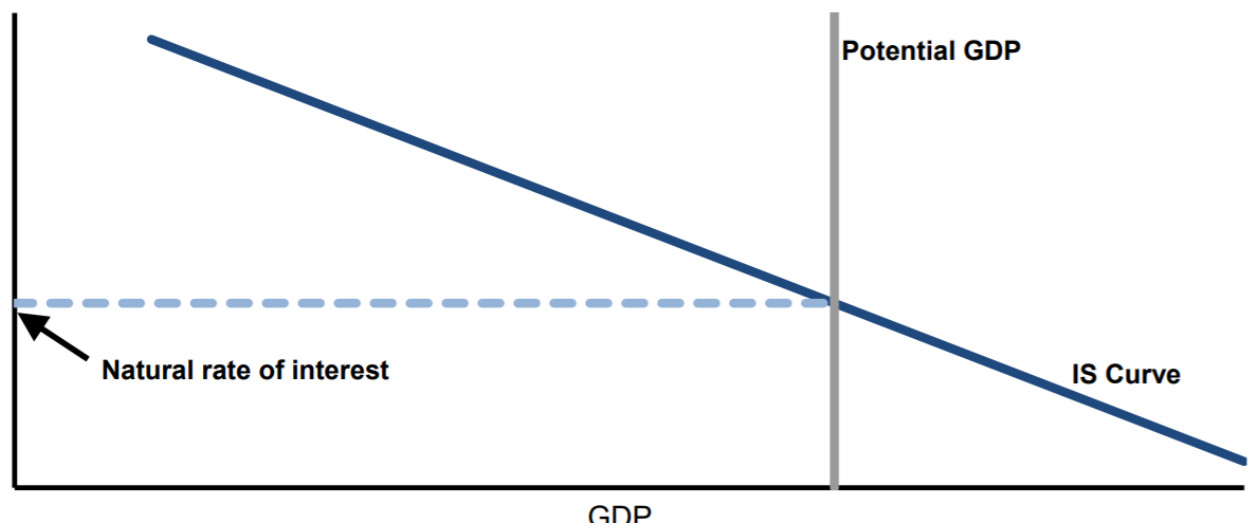

Figure 1. Determination of Interest rate. Source: Laubach\&Williams (2015)

If investments rise and by doing so raise the interest rate then the Central Bank may not want to intervene to curb the growth in investments and also hamper with the corrective tool of the market, the rise in the interest rate. A rise in the interest rate may be good for the economy because it will help cool of the economy.

But if the rise in the interest rates is caused by a decline in the supply of loanable funds than the bank may want to intervene.

Interest rate differentials: Another problem with using interest rate as instrument to monetary policy is the inability of the central bank to control the spread between deposits and credit

Lag of interest rate policy: A third problem with using interest rate as instrument of monetary policy is that the interest rate effects the aggregate demand and supply of funds with a lag due to adjustments costs. According to the literature there are two aspects of this lag: its

length and variability. The former is often assessed at about six quarters to two years in the United States, Britain and Canada. While there is agreement that there is some variability in the length of the lag, there is no consensus on whether it is so long that changes in interest rates, intended to be stabilizing, can prove to be destabilizing. Within the lag, the impact effect (within the same quarter) of interest rate changes on real aggregate demand is estimated to be quite low, while the long-run effect is now believed to be very significant. 
Albania changed its main instrument of Monetary policy during the Financial crises, 2008. It went from controlling money supply to setting policy "repo" interest rate in order to control inflation. Inflation, though, has been under the targeted objective and has been combined with a strong currency, vs. the euro, and moderate GDP growth. Because of these factors the Bank of Albania has continued to maintain an accommodative Monetary Policy with historically low repo rate.

\section{Taylor Rule}

Taylor Rule was created by John Taylor in his 1993 paper famous paper "Discretion versus policy rules in practice". It was followed a another paper in 1999 that proposed a modified Taylor Rule where the coefficient of the deviation of current output from current output was given a value of 1 versus 0.5 in the original rule. Taylor Rule is a backward looking rule. It means that the interest rate is based on past inflation and past economic growth deviation from trend.

\section{$r T t=r 0+\alpha(y t-y f)+\beta(\pi t-\pi T) \alpha, \beta>0$}

Taylor Rule is widely used in monetary policy to establish policy interest rate.

According to Janet Yellen (Yellen,2015) the simple Taylor Rule can be used to establish federal funds rate. In 2015 the Taylor Rule called for the ffr to be close to zero. Yellen write then that she disagrees with the implications of the rule for two reasons: first because unemployment slack is higher than the measurement of that time and second because of the equilibrium real ffr is low by historica standards. By arguing this Yellen is implying that a corrected Taylor Rule would better express the policy of the FEDs fund rate.

Taylor (1996) ${ }^{1}$ says that the effectiveness of monetary policy can be improved through better inflation measurement, understanding better the transmission mechanism of monetary policy and through regulation, or in some cases deregulation, by achieving a better management of the banking system and institutions.

Governor Janet Yellen indicated that she used the Taylor rule to provide her "a rough sense of whether or not the funds rate is at a reasonable level"2 (FOMC transcripts, January 31-February 1, 1995).

According to this approach Albania's currency is faced with a challenge by the monetary Policy of ECB. With it's accommodative moentary Policy ECB is making it more attractive for Albanian immigrants to send money "home" to buy assets and consumption. This money come in through remittances and BOP

Bank of Albania (BoA) changed in 2008 the intermediate instrument of monetary policy by targeting interest rate instead of money supply.

\section{Data}

But one fact that has been underestimated in the policy goals is the fact that our money supply, and the demand for money, is independent with the foreign currency most dominant in our economy, i.e. euro. Since over $50 \%$ of our deposits and loans are made in euros any decision on the interest rate of ALL should take into account the interest rate of loans and deposits in euro. This is because of two reasons

\section{i. Replacement of the product}

If the interest rate on loans denominated in ALL is higher than that in Euro than we would expect the rational economic agents to demand more loans in Euro rather than ALL. This replacement offsets any objectives that BoA, or any central bank with highly dollarized economy, wishes to have.

ii. The supply of euro

An interest rate of ALL much higher than that in euro area, as has been the case in the last 19 years since the launching of the euro, tends to raise the demand for loans in euro making euro a less good option to save and increasing the 
propensity of the holders of euro currency to make purchases denominated in euro. When holders of euros make purchases denominated in euros it fuels the euroization of the economy.

iii. Remittances preasure on monetary policy

Remittances fund a huge deficit in the Albania's large deficit of BOP. Remittances can

After European crises, which saw a gradual decline in remitances the amount euros immigrants bring to Albaina and invest here has increased.

\section{Remittances, official aid for develoment and FDIs in \% to GDP}

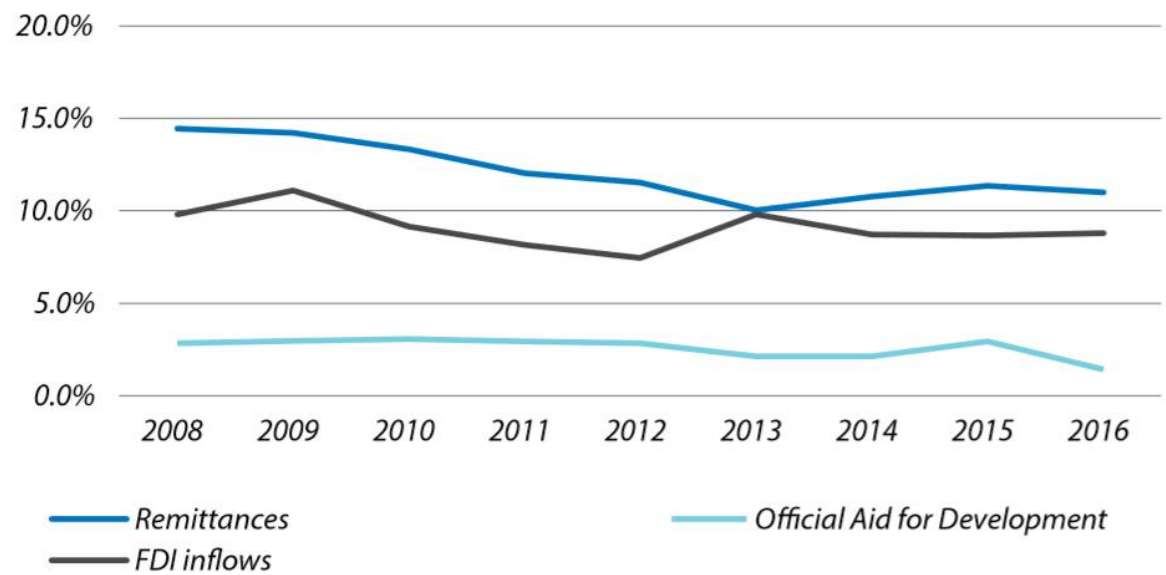

Source: Bank of Albania, for Remittances and FDls. http://data.worldbank.org/indicator/DT.ODA.ALLD.CD for Official Aid for Development.

First, remittances have picked up in the impact in the GDP expressed as a percentage but are still much lower than that in the pre crises levels. FDI is below but close to the long term average and the aid transfers have been falling.

Despite the steady influx of euros, it is significant that ALL has become a stronger currency. It seems obvious that the monetary policy in Albania has been tighter and has not considered development of the money markets of our main economic and trading partner, EU.

According to Taylor (1996) and logic we should assume that the basic principal of policy analysis be based on a coherent theory of how policy rules affect the economy and be supported by econometric models.

Thus having this high level of euroization we can propose two additional indicators that impact the policy interest rate of the CB in the Taylor model.

i. Policy interest rate of the euro by ECB

Because banks have the free flow of capital and a low interest rate by ECB makes Albanian's market for loans in euro more attractive. 
Taylor's original rule is backward looking, but several recent versions of the rule include an expectation factor. Clarida, Gali and Gertler (1998) reject the backward looking rule in favour of a forward looking rule. However, they include the lagged interest rate as a regressor, thus formally making it a hybrid rule.

ii. Balance of payments of Albania

A strong home currency adversely affects the competitiveness of our economy but putting our products at a disadvantage.

An issue actively pursued in further research on the Taylor rule has been whether or not asset prices and exchange rates should be included in this rule. The argument in favor of their inclusion is that shifts in them can change aggregate demand. However, some part of these shifts are often the result of changes in output and inflation, so that only the impact of their residual shifts on inflation and output would need to be offset through monetary policy. Doing so yields extended forms of the Taylor rule. Many empirical studies report that using some form of an augmented Taylor rule, such as incorporating changes in wealth or house prices or exchange rates, leads to greater stabilization of the economy.

\section{Economic Model}

Albania is highly dollarized with Euro being using in more than $50 \%$ of the economy. Thus the interest rate of ECB influences our economy. Taylor rule will perform better to economic conditions when We use a two-country model, with most variables defined as the difference between a home country Albania and a foreign country, the US.

The " $h$ " identifies the home country, and "*" the foreign country. The monetary rules in the foreign and home countries are:

$$
\begin{aligned}
& i_{t}^{*}=\gamma_{\pi} E_{t} \pi^{*}{ }_{t+1}+\gamma_{y} y^{*}{ }_{t}+u^{*}{ }_{m t} \\
& i_{t}{ }_{t}=\gamma_{q} i_{t}^{*}+\gamma_{\pi} E_{t} \pi^{h_{t+1}}+\gamma_{y} y^{h_{t}}+\gamma_{s t} q_{t}+u^{h_{m t}}
\end{aligned}
$$

In Equations (8) and (9), $i^{*}$ is the interest rate in the foreign country, $i_{t} t_{t}$ the interest rate in the home country, and the variable $i_{t}$ is defined as: $i_{t}=i_{t}-i_{t}^{*}$

Where:

it: difference between home and foreign interest rates; for it and other variables, an increase indicates a rise in home relative to foreign rates; all interest rates are expressed at annual rates;

yt: difference between home and foreign deviation of log output from trend;

$\mathrm{p}_{\mathrm{t}}$ : difference between home and foreign log price levels;

$\pi_{\mathrm{t}}$ : difference between home and foreign inflation (with inflation first difference of log consumer price level [CPI]);

umt: difference between home and foreign shocks to monetary policy rule;

St: log nominal exchange rate (e.g., ALL/Euro, when Albania is the home country);

$\mathrm{q}_{\mathrm{t}}=\mathrm{s}_{\mathrm{t}}-\mathrm{p}_{\mathrm{t}} \mathrm{l} \log$ real exchange rate;

$\mathrm{E}_{\mathrm{t}}$ : mathematical expectations conditional on a period $t$ information set.

\section{Conclusions}

Central Bank of Albania has followed an accommodative MP following the aftereffects of the Great Recession in Albania. We conclude that dollarization of Albanian economy, by the euro, has hampered the efforts by the Central Bank to bolster economic recovery. Natural rate of interest is in the negative territory and the policy real interest rate of the Central Bank has not fallen below the natural rate of interest. A policy real interest rate below the natural rate of interest is a policy that is accommodative.

We propose an adjusted Taylor rule that includes foreign country interest rate differentials and exchange rate. This would model would: 
When foreign interest rate differential: In this case we would have a negative effect on the home interest rate. When the foreign country whose currency circulates largely (Euro zone in this case) in the home country, Albania, lowers their interest rate it would have a similar downward effect on the home country policy interest rate.

Exchange rate: A strong home currency versus the foreign currency denotes a high demand for the local currency versus the foreign currency or a shortage of money supply. Central bank would like for the national economy to be competitive to raise exports and improve on the balance of payments. A strong home currency should have an effect on policy interest rate of the home country. A weak currency is a signal of the excess money supply denominated in ALL or a decline in the demand for money.

We recommend the adjusted Taylor Rule for Monetary Policy with foreign country interest rate and exchange rate.

\section{References}

[1] Castelnuovo, Efrem. 2003. ITaylor rules, omitted variables, and interest rate smoothing in the US." Economics Letters $81: 55\{59$

[2] Taylor (1996 - Policy Rules as a means to a more effective monetary policy: page 1) FOMC transcripts, January 31-February 1, 1995).

[3] 1 Bank of Albania: Argita Frashëri, Valentina Semi, Rudina Lilaj, Enian Çela, Lindita Vrioni, Arlinda Koleniço. Remittances: 16 June 2018

[4] Mishkin, Frederic. 2009. Is Monetary Policy E_ective during Financial Crises?" NBER working paper series (14678).

[5] Pier Francesco Asso, George A. Kahn, and Robert Leeson, 2010 RWP 10-05 The Taylor Rule and the Practice of Central Banking

[6] Milton Friedman. 1996. The Role of Monetary Policy The American Economic Review, Vol. 58, No. 1. (Mar., 1968), pp. 1-17.

[7] John B. Taylor. 1993. Discretion versus policy rules in practice "Stanford University, Stanford, CA 94905".

[8] John B Taylor. 1996. Policy Rules as a means to a more effective Monetary Policy

[9] John B. Taylor. 2001. The Role of the Exchange Rate in Monetary Policy Rules 